\title{
IAMJ
}

INTERNATIONAL

AYURVEDIC

MEDICAL JOURNAL

ISSN: 2320-5091

Impact Factor: 6.719

\section{GRAHABADHA- A STUDY OF MICROBIAL INFECTION IN ANCIENT TIMES}

\author{
Snehal Vinayak Kale ${ }^{1}$, Mangesh Madhusudan Pawar $^{2}$ \\ ${ }^{1}$ PhD Scholar (Balroga), M.D. Balroga, Assistant Professor Balroga Dept. \\ Yashawantrao Chavan Ayurved Medical Collage, Aurangabad, Maharashtra, India \\ ${ }^{2}$ M.D. Rog Nidana \& Vikriti Vigyana, Assistant Professor Rog Nidana \& Vikriti Vigyana Dept. \\ Yashawantrao Chavan Ayurved Medical Collage, Aurangabad, Maharashtra, India
}

Corresponding Author: snehalvkale088@gmail.com

https://doi.org/10.46607/iamj2309022021

(Published online: February 2021)

Open Access

(C) International Ayurvedic Medical Journal, India 2021

Article Received: 01/02/2021 - Peer Reviewed: 06/02/2021 - Accepted for Publication: 08/02/2021

Check for updates

\begin{abstract}
Ayurveda is the oldest and time tested rich medical science which has been protecting our health since centuries. Ayurveda is systematically divided into eight clinical branches. Among them Vagbhata have given third place for Grahabadha. Ashtang hridaya, Sushruta and Madhava Nidan have explained Grahabadha in detail while Chara$k a$ is silent about Grahabadha. Later there are many books which copy the same with slight difference. Coherence in understanding the principles of Ayurveda is very essential to understand and apply them into practice. There is no clear-cut description of microbial infection in ayurvedic texts. But the description of unidentified vectors is found scattered in our texts like- Skanda, Putana, Revati, etc. These terms have been mentioned collectively under the description of Grahabadha when considered individually they resemble some of the clinical features and associated features of microbial infection. After complete study of concept of Grahabadha it is concluded that these unidentified vectors are thought to be microbes, which cannot be seen by naked eyes but produce group of diseases of multi systemic origin and syndromes.
\end{abstract}

Keywords: Grahabadha, microbial infection, unidentified vectors 


\section{INTRODUCTION}

Graharogas constitutes the major portion of Kaumarbhritya branch either Ashtanga karas have given notable importance to Graharogas by giving them third place in Ashtang ayurveda ${ }^{1}$. Besides that, due to its extravagant mythological explanations, difficulties in clinical understanding, diagnosis and treatment it is the most neglected portion of Kaumarbhritya. Contemporary modern science doesn't explain the cause of disease when cause is invisible. They depend upon the techniques and investigations like CT scan, M.R.I. scan, blood investigations, urine investigations in case of invisible cause. But if the cause is not detected even by these advanced techniques and investigations then they term these diseases as disease of unknown origin or idiopathic nature of diseases. Ayurveda have faith on Karya karan vada means for every consequence there will be a cause which may be visible or invisi- ble. If the cause is invisible but the disease is chronic in presentation, they can be named as poorva karmaja, Aatma karmaja, Daivika shakti, etc. But if the cause is invisible and disease is acute in presentation, they can be named as Bhoota, Preta, Pisacha, Grahabadha, Jataharini, etc. Hence Graharogas are counted in acute severe presentation with cause is invisible. In ancient times invisible causes like Grahabahda are identified by divine vision (Shastra chakshu) ${ }^{2}$ or vision of knowledge (Divya chaksh) as the techniques and instrument like microscopes are not available in those days.

Nature of Grahas: Balagraha is a combination of two words Bala + Graha. Bala means children while 'Graha' means to grasp or seize. Grahas- a class of evil demons supposed to capture or affect the children and produced various clinical features.

Table 1: Similarities between Graha and Micro-organisms

\begin{tabular}{|c|c|c|}
\hline Nature & Graha & Micro-organisms \\
\hline Living & Living (As they move and attack) & Living \\
\hline Prone time of movement & Night hours ${ }^{3}$ & Dark area/ Low temperature areas \\
\hline Incubation period & $\begin{array}{l}\text { Follow (entry can't be identified after invasion } \\
\text { to the production of first symptom) }\end{array}$ & Follow \\
\hline Size and Shape & $\begin{array}{l}\text { Changes size and shape frequently as per de- } \\
\text { mand }^{4}\end{array}$ & $\begin{array}{l}\text { Pass through stages of life cycle like larva, } \\
\text { egg, mature, spores, etc. }\end{array}$ \\
\hline Visibility & $\begin{array}{l}\text { Invisible and visible only through certain spe- } \\
\text { cial vision power (Dnyan chakshu) }\end{array}$ & $\begin{array}{l}\text { Invisible by naked eyes and visible by mi- } \\
\text { croscopes }\end{array}$ \\
\hline Entry inside the body & $\begin{array}{l}\text { Enters in those who are Ashuchi and don't fol- } \\
\text { low the general rules of lifestyle }\end{array}$ & Enters in those who are immune-deficient \\
\hline
\end{tabular}

Physiological nature of Grahas (Micro-organisms): The mythological concept that Grahas are produced from Shiva and Parvati for protective purpose of their son Kartikeya explains the physiological nature of Grahas $^{6}$. Strongest among all these Grahas is Skanda Graha as Lord Shiva pointed him as chief of all Grahas and also called as Baladhara ${ }^{7}$. But if we assume Grahas are micro-organisms then how they can protect us?

As it is well understood concept, that an infection caused by micro-organism will always leave back certain degree of immunity against that species and formation of memory cells and reduce the severity of the same infection in future. That means micro-organisms serve the function of protection after infection ${ }^{8}$.

Pathological nature of Grahas (Micro-organisms): Ashuchi and disobeying the rules of Swasthavritta plays important role in turning Grahas to pathological in nature. Disobeying the rules i.e. human errors will creates loophole in human body. Ashuchi i.e. unhygienic food, lifestyle, overcoming rules of Dinacharya, Rutucharya, Sadvritta and Swasthavritta, Hina, Mithya or Ati yoga of everything becomes responsible for the invasion of Grahas and micro-organisms also.

Etio-pathology of Grahas: Graha rogas differs from other general disorders as they show different etiological factors, symptoms and management. There will be 
no Dosha vitiation in the beginning and causes are invisible and Agantuja in nature. Ashuchi and disobeying the rules of Swasthavritta are the main reasons to form pathology of Grahas. Sushruta described that the reason of Graharogas are, Disobeying of rules and regulation of Sadwritta and Swasthawritta of child and mothers leading to personal, social and environmental hazards e.g., not trimming the nails once in a week leads to collection of fecal and other waste products in the nail bed, which act as a shelter for the growth of micro-organisms. Feeding in unclean and broken vessel with unhealthy conditions of surrounding environment ${ }^{9}$ e.g. food accumulated in broken vessel may create a fermenting media for the growth of micro-organisms. excessive satisfaction of child's Dhatri (wet nurse) or mother in eating, sleep, exercise, sex ${ }^{10}$ e.g. as the child is depends on the mother for feeding and other demands related to health and hygiene it is important to maintained mothers personal and social hygiene. harmful activities and unreligious conducts e.g. child will be easily victim by Graharogas, after a event or act which produce fear like tossing the child in air, crossing or jumping over $i^{11}{ }^{11}$ psychological aspect of children e.g., role of Manas in the causation of psychosomatic disorders is well known fact. misbehaving in front of priest, disrespect of saints, teachers, and Gurus e.g., Teachers are the main source of knowledge and disobeying and disrespecting their advice leads to disease state which are due to lack of knowledge required to follow healthy life. These things create a weak point in the body's immune system of child which can easily invite the Grahas (micro-organisms) to enter in the body for Badha (infection).

\section{Purpose of Grahas (Micro-organisms) to enter in body:}

Grahas (micro-organisms) enters in body mainly for three purposes- Himsa, Rati, and Archana ${ }^{12}$.

1. Himsa- Here Himsa is narrated with the meaning of giving pain, to create injury instead of killing. We all know that when micro-organisms enter in the body they undergo with antigen-antibody reaction mediated by body's immune system which further leads to phagocytosis and tissue injury. It results in certain symptoms like fever, sneezing, allergic reactions, etc. which is nothing but painful suffering or Himsa. Viruses also enter in the body, and then explode to release chemicals to cause tissue injury (Himsa) and initiate inflammatory responses.

2. Rati-Here Rati is narrated with the meaning of manipulation of body parts to yield the pleasure of sexual act or desire. We know that a strong sexual thirst of micro-organisms compels them to find a definite or an indefinite host to complete their life cycle of reproduction. They enter in the body as an egg and complete their life cycle by converting into a gametocyte and then exit the body. Malarial parasite is the best example of that.

3. Archana-Here Archana is narrated with the meaning of get nourished, worshipped. Certain groups of micro-organisms enter inside the body with the intention of getting nourishment to increase their colonies and produce disease. Typhoid and Shigella like pathogens and tubercular bacteria are some best examples of that. So, first purpose illustrates pathogenic nature of micro-organism to creates a disease, second microbes enter in the body to complete their life cycle and create a disease, third one explains using host by microbes to get their nutrition. These tendencies of micro- organisms might have been referred as Himsa, Rati and Archana. But this entry can be possible only when there is a loophole in the human body due to Ashuchi acharana.

Mode of action of Grahas: Grahas enters inside the body like entry of Atma inside the body, entry of light ray or image inside the mirror, Taila inside the Beeja, Shita and Ushna guna pravesh inside the body, entry of sun rays inside the Suryakanta gem $^{13}$.

Incubation period of Graha: Incubation period is the time interval between the entries of micro-organisms inside the body till it produce first symptom. Incubation period like presentation is also seen in Grahas as the entry of Graha inside the body can't be identified and only the first symptom gives the clue.

Similarity between Morphology, habitat and characteristic of Grahas and Micro-organisms: 
Mahabharata first time explained the morphology of phology of certain micro-organisms. certain Grahas which can be correlated with the mor-

Table 2: Correlation between morphology of Grahas and micro-organisms

\begin{tabular}{|l|l|}
\hline Grahas $^{\mathbf{1 5}}$ & Micro-organisms \\
\hline Grahas resides near Goshala & Acide resistant bacteria \\
\hline Grahas resides in Shunnyagara & Anaerobic bacteria \\
\hline Grahas which are Aakashachari & Aerobic bacteria \\
\hline Grahas having fond of red flowers, garlands, cloths & Bacteria or fungi which grow in fermenting medium \\
\hline Grahas which produced from Agni & Haematogenous bacteria \\
\hline Grahas which are Tejaswi, Yashaswi, Balavan & Heat resistant micro-organisms \\
\hline Grahas named after the Bird like Shakuni & Potent and virulent micro-organisms \\
\hline Grahas named after the animal like Naigamesh & Micro-organism which uses bird as its host \\
\hline Grahas produce after severe war & Micro-organisms responsible for cattle born disorders \\
\hline Ugly looking Grahas & Micro-organisms developed as a post war complication \\
\hline Jataharini attacks pregnant woman & Micro-organisms produced in extreme unhygienic areas \\
\hline Vitiates breast milk of Dhatri too & As foetti are highly contagious to micro-organisms \\
\hline
\end{tabular}

This description of microscopic morphology, survival in unhygienic atmosphere and blood medium as positive culture, more sustenance in darkness and low temperature when the individual's BMR also remains low exactly indicates that Grahas are no other than, the microorganisms like virus, bacteria etc.

Prodromal Symptoms: Continuous crying and fever are only two prodromal symptoms which are defined in various textbook of ayurveda ${ }^{16}$. Due to limitations in language development in newborns they denote the same symptom to indicate many diseases and i.e., cry- ing. But continuous cry, vigorous inconsolable cry, fearful continuous cry is a characteristic symptom to infer the only Graha badha. As fever is the most common symptom of almost all the infective cases with some rare exceptions it helps us to understand the antigenicity and infective nature of the Grahas.

General Symptoms: The symptoms appearing in a child due to affection of Graha Badha may depend upon the infliction of that particular Graha. Given table shows the various symptoms of Bala Grahas ${ }^{17,18}$

Table 3: Various symptoms of Bala Grahas

\begin{tabular}{|l|l|}
\hline Particulars & Symptoms \\
$\begin{array}{l}\text { General Symp- } \\
\text { toms }\end{array}$ & $\begin{array}{l}\text { Fever, irritability, excessive crying, yawning, shouting, bites lips, clenches teeth, clenches fists, injures } \\
\text { himself or the mother with the nails or teeth, refusal to take feeds, emaciation, excessive lacrimation, } \\
\text { rubs his eyes, ears and nose miserable look, eyes become red etc, }\end{array}$ \\
\hline $\begin{array}{l}\text { Psychological } \\
\text { Systral Nervous }\end{array}$ & $\begin{array}{l}\text { Fear, pulls his hairs, laughs alone without any reason and becomes cruel. } \\
\text { Vacant stare, unconsciousness, drowsiness, giddiness, irritability, hypotonia, rolling of eyeballs, jerky } \\
\text { movements of head, twitching of eyelids and facial muscles, tremors, defective posture, dribbling of } \\
\text { saliva (due to facial palsy), change in voice and speech, incontinence of urine and stool, fainting, etc. }\end{array}$ \\
\hline $\begin{array}{l}\text { Gastro -intestinal } \\
\text { symptoms }\end{array}$ & Diarrhea, distension, vomiting thirst, constipation, stomatitis, distention of abdomen, etc. \\
\hline $\begin{array}{l}\text { Respiratory } \\
\text { Symptoms }\end{array}$ & Cough, hiccup, grunting respiration, change in voice, dysponea, running nose. etc. \\
\hline $\begin{array}{l}\text { Skin } \\
\text { Smell of body }\end{array}$ & $\begin{array}{l}\text { Change in colour of skin, blisters urticaria, prominent veins over skin of abdomen, etc. } \\
\text { according to influence of particular Grahas. }\end{array}$ \\
\hline
\end{tabular}




\section{Treatment principles of Graha Rogas:}

Treatment of Graha Rogas includes both Daiva and Yukti vyapashraya chikitsa ${ }^{19}$. Daiva vyapashraya chikitsa is an Adravyabhuta chikitsa which helps to correct the disturbed mind. Ayurveda believes in global approach, so, treatment of mind is equally important to correct a physical illness. Also, if we see Purva roopa of Graha roga is narrated as Jwara and main symptom of Jwara is Santapa. Santapa can affect both body and mind. Modern science also says that every disorder is a psycho-somatic disorder, so, Daiva vyapashraya chikitsa can be employed in each and every case.

Scientific view of Graha Chikitsa:

\section{Diava vyapashraya Chikitsa-}

1. Mantra chikitsa ${ }^{20}$ - Mantra Chikitsa is not just limited up to chanting of certain Mantra with certain religious intentions which is related with God. Mantras when chanted in a rhythmic way create sound waves of different wavelengths and amplitudes which are able to modulate the electromagnetic wave patterns of the brain. They keep the mind in a positive attitude and remove the negativity of the mind. Different Mantras of different Grahas contains details of individual Grahas, its greatness, and its method of worship, clinical symptoms and details of treatment. So, doctors get revised with the subject concerned who helps them for management. Further Mantra chikitsa can be correlated with music therapy.

2. Swasthi vachana- Meaning of Swasthi vachana is to pray for welfare of the patient. This can be correlated with counseling of the patient and make him realize the true facts of health.

3. Bali chikitsa ${ }^{21}$ - The word Bali is not involved in just killing the animals, as a ritual of satisfaction of God and the evil spirits but Bali is the method of mass-disinfection or community disinfection adopted by Ayurveda. Micro-organisms are very virulent in the society, spreads the diseases from person to person. Their normal tendency is to move towards the host. Crossroads, temple, dark areas, near tree, etc are the areas where maximum contamination is predicted due to movement of crowd where Bali is offered. Meat of different animals easily gets necrosis, putre- faction with bad smell and provides a favorable medium for the growth of micro-organisms. Vegetarian foods like payasa, mudga, paya, godhuma, etc. are also used for Bali as they undergo fermentation process and provide medium for growth of microorganisms and also attracts surrounding microorganisms towards it. So, Bali acts as a natural culture medium for the growth of micro-organisms.

4. Vastra pradan chikitsa ${ }^{22}$-Our skin has bacteria on the surface of our skin, in our nose and in our gut, many skin conditions can easily transfer through cloths. So, Vastra pradan is one of the ways of disinfection adopted by Ayurveda.

5. Mangala homa and havana chikitsa ${ }^{23}$ - In an ancient period Homa is done to assess the prognosis of Graha rogas. As the body surface of Graha rogi emits different abnormal smells, which when comes in contact with the fire may give different colors to fumes. Also, expiratory air of a Graha rogi may contain certain abnormal metabolic toxic compounds, which on contact with the fire may give different colors to the fumes. Also, by this method air gets purified by medicinal fumes and environmental pathogens are cleared off along with their individual effects.

\section{Yukti vyapashraya chikitsa-}

1. Oushadhi dharana chikitsa ${ }^{24}$ - Drugs tied in Pottali for and then tied around the neck of child in Oushadhi dharana chikitsa. Drugs used for that are having strong aromatic smell which easily prevents the communication of the diseases by droplet or through air born infection. Also, these drugs can be used as emergency measures. So, principle behind the Oushadhi dharana ensures the disinfectant nature and being ready for emergency measures if needed.

2. Snana chikitsa $\mathbf{2 5}^{25}$-For Snana purpose it is advised to use Aushadhi siddha koshna jala. Drugs like agnimantha, nimba, shigru, karanja, paribhadra, etc. are used for the purpose having Kashaya rasa and antiseptic properties. Bathing with these drugs Siddha koshna jala helps to remove bad smell, gives freshness and avoids contamination of the skin by the accumulation of unhygienic substances. 
3. Ghrita prayoga ${ }^{26}$ - Pharmacologically, a Ghrita preparation helps the chemical constituents to dissolve in lipid media and facilitating its easy absorption.

4. Parishekh and Avagaha ${ }^{27}$ - Avagaha and parishekh done with the help of water medicated with the drugs having antiseptic properties. Both acts externally and prevent the spread of infection, overcome the bad smell, sterilize the wound and avoid contamination.

5. Lepas $^{28}$ - External application of Lepa prevents the spread of infection through the bite of mosquitoes and also overcomes the bad smell.

6. Dhupana chikitsa ${ }^{29}$ - In Dhupana drugs are made to burn in lipid medium like Ghrita, Taila. Drugs are present in solid form but after burning get converted into a gaseous form and easily get absorbed from mucus membrane of respiratory track to yield beneficial effects. Inhalation therapies like puffs, spacers, nebulization are also having the similar principle. Dhupana using Naadi (tube) gives nebulization like effect. Drugs used for Dhupana like vacha, guggulu, jatipushpa, etc. are having strong aromatic smell. Strong smell of Dhupana acts as a potent antibacterial agent and clears the micro-organisms. Certain animal products like skin of snake, fecal matter of animals and birds are also used for Dhupana as they emit bad smell and rich in urea, uric acid, ammonia and release some chemicals with oxides when burnt to yield beneficial effect. So, Dhupana acts as an antibacterial, antimicrobial, antiseptic, disinfectant, bactericidal and bacteriostatic in nature and can be used for sterilization of individual, room and belongings.

7. Dhoomapana- Dhoomapana is the highly individualistic disinfectant procedure. Drugs having anti-infective, disinfectant, antiseptic properties and of nature like katu, tikta, kashaya ras, with ushna, tikshna, sukshma and shlakshna qualities are made into a wick and burnt and their fumes are inhaled to yield beneficial effect. So, all these concepts are completely scientific, and they aim to prevent infection individually, in community or among the masses.

\section{DISCUSSION}

Graha roga is the most neglected portion due to its excess mythological explanations, difficulties in clinical understanding, diagnosis and treatment. Though aetiopathogenesis, general symptoms of Graha has now been felt as fake among scholars but really, they are explained in an applied clinical manner. They movement and attacking nature, their prone time of movement, method of invasion, change in size and shape, their intention to enter inside the body, invisibility by naked eyes, having fever as the main symptom, etc. all these particulars shows similarities with Micro-organisms. Also, the way of treatment measures mentioned earlier gives priority to absolute hygiene and immunity besides symptomatic management. Acts as an antibacterial, antimicrobial, antiseptic, disinfectant, bactericidal and bacteriostatic in nature and can be used for sterilization of individual, belongings, community and masses.

\section{CONCLUSION}

In a nutshell Graha are not mythological and now compared with various microbial infections which can be treated with a combined approach of therapeutic and psychiatric management. Thus, this arise the importance of cleanliness and hygienic measures to adopt in routine practice. The abode of pregnant woman and child is to be kept clean, well fumigated by various protective measures prescribed for child and puerperal woman are measures to prevent infection. The review of Literature also supports the use of these ayurvedic Chikitsa not only to treat Graha Roga but also as agent to prevent or control the bacterial infections. However here is an effort done by author to fulfill lacuna in understanding of Graha badha or Rogas but may require further modification in future.

\section{REFERENCES}

1. Ashtanga Hridaya edited by Dr. Brahmanand Tripathi with Hindi commentary Nirmala, Reprint edition 2009, Sutra Sthana, Adhyaya 1, Shloka No. 5, Chaukhamba Sanskrit Prakashana, Delhi, Page No.5 
2. Ashtanga Sangraha Uttar Sthana, Adhyaya 3, Shloka No. 35

3. Sushruta Samhita edited by Dr. Ananta Ram Sharma with Hindi commentary Susrutavimarshini, Reprint edition 2009, Uttar Tantra, Adhyaya 60, Shloka No. 3, Chaukhamba Surabharati Prakashana, Varanasi, Page No. 486

4. Sushruta Samhita edited by Dr. Ananta Ram Sharma with Hindi commentary Susrutavimarshini, Reprint edition 2009, Uttar Tantra, Adhyaya 60, Shloka No. 6, Chaukhamba Surabharati Prakashana, Varanasi, Page No. 487

5. Sushruta Samhita edited by Dr. Ananta Ram Sharma with Hindi commentary Susrutavimarshini, Reprint edition 2009, Uttar Tantra, Adhyaya 60, Shloka No. 5, Chaukhamba Surabharati Prakashana, Varanasi, Page No. 486

6. Ashtanga Hridaya edited by Dr. Brahmanand Tripathi with Hindi commentary Nirmala, Reprint edition 2009, Uttar Sthana, Adhyaya 3, Shloka No. 1, Chaukhamba Sanskrit Prakashana, Delhi, Page No.900

7. Ashtang Sangraha Uttarshtana, Adhyaya 3, Shloka No.1

8. www.koshland-sciencemuseum.org/sites/all/exhibits/exhib__ infectious/vaccines_10.jsp

9. Sushrita Samhita edited by Dr. Ananta Ram Sharma with Hindi commentary Susrutavimarshini, Reprint edition 2009, Sharira Sthana, Adhyaya 10, Chaukhamba Surabharati Prakashana, Varanasi

10. SushrutaSamhita edited by Dr. Ananta Ram Sharma with Hindi commentary Susrutavimarshini, Reprint edition 2009, Uttar Tantra, Adhyaya 27, Shloka No. 6, Chaukhamba Surabharati Prakashana, Varanasi, Page No. 200

11. Charaka Samhita, Sharira Sthana, Adhyaya 8. Shloka 68

12. Ashtanga Hridaya edited by Dr. Brahmanand Tripathi with Hindi commentary Nirmala, Reprint edition 2009 , Uttar Sthana, Adhyaya 3, Shloka No. 32, Chaukhamba Sanskrit Prakashana, Delhi, Page No.903

13. Sushruta Samhita edited by Dr. Ananta Ram Sharma with Hindi commentary Susrutavimarshini, Reprint edition 2009, Uttar Tantra, Adhyaya 60, Shloka No. 19, Chaukhamba Surabharati Prakashana, Varanasi, Page No. 490

14. Charaka Samhita, Chikitsa Sthana, Adhyaya 9, Shloka No.18

15. Shushruta Samhita edited by Dr. Ananta Ram Sharma with Hindi commentary Susrutavimarshini, Reprint edition 2009, Uttar Tantra, Adhyaya 27-36, Chaukhamba Surabharati Prakashana, Varanasi

16. Vagbhatta, Astanga Hridaya edited by Kaviraj Atridev Gupta with Hindi commentary Vidyotini, Reprint edition, Uttara Tantra, verse no. 3/3, Chaukhambha Sanskrit Sansthan, Varanasi, India; 2005. p. 461.
17. Vagbhatta, Astanga Hridaya edited by Kaviraj Atridev Gupta with Hindi commentary Vidyotini, Reprint edition, Uttara Tantra, Adhyaya 3, Shloka No.4-5, Chaukhambha Sanskrit Sansthan, Varanasi, India; 2005. p. 461.

18. Sushruta Samhita edited by Kaviraja Dr Ambika Dutta Shastri with Hindi Commentary Ayurved Tatva Sandipika $12^{\text {th }}$ edition, Volume - I Sharira Sthana, Verse no. 10/56, Chaukhamba Sanskrit Sansthan. Varanasi, India; 2001. p. 81.

19. Ashtanga Sangraha, Uttarsthana, Adhyaya 2, Shloka No. 98

20. Ashtanga Hridaya edited by Dr. Brahmanand Tripathi with Hindi commentary Nirmala, Reprint edition 2009, Uttar Sthana, Adhyaya 3, Shloka No. 58, Chaukhamba Sanskrit Prakashana, Delhi, Page No.906

21. Sushruta Samhita edited by Dr. Ananta Ram Sharma with Hindi commentary Susrutavimarshini, Reprint edition 2009, Uttar Tantra, Adhyaya 60, Shloka No. 32-37, Chaukhamba Surabharati Prakashana, Varanasi, Page No. 492-493

22. Sushruta Samhita edited by Dr. Ananta Ram Sharma with Hindi commentary Susrutavimarshini, Reprint edition 2009, Uttar Tantra, Adhyaya 60, Shloka No. 31, Chaukhamba Surabharati Prakashana, Varanasi, Page No. 492

23. Ashtang Sangraha, Uttarsthana, Adhyaya 4, Shloka No. 13-15

24. Ashtanga Sangraha, Uttarsthana, Adhyaya 6) (Sushruta Samhita, Uttarshtana Adhyaya 28-36

25. Ashtanga Hridaya edited by Dr. Brahmanand Tripathi with Hindi commentary Nirmala, Reprint edition 2009, Uttar Sthana, Adhyaya 3, Shloka No. 44-45, Chaukhamba Sanskrit Prakashana, Delhi, Page No.904

26. Ashtanga Hridaya edited by Dr. Brahmanand Tripathi with Hindi commentary Nirmala, Reprint edition 2009, Uttar Sthana, Adhyaya 3, Shloka No. 49-57, Chaukhamba Sanskrit Prakashana, Delhi, Page No.905

27. Ashtanga Sangraha, Uttarsthana, Adhyaya 6

28. Ashtanga Sangraha, Uttarsthana, Adhyaya 6

29. Ashtanga Hridaya edited by Dr. Brahmanand Tripathi with Hindi commentary Nirmala, Reprint edition 2009, Uttar Sthana, Adhyaya 3, Shloka No. 46-48, Chaukhamba Sanskrit Prakashana, Delhi, Page No.904-905

\section{Source of Support: Nil \\ Conflict of Interest: None Declared}

How to cite this URL: Snehal Vinayak Kale \& Mangesh Madhusudan Pawar: Grahabadha- A Study Of Microbial Infection In Ancient Times. International Ayurvedic Medical Journal \{online\} 2021 cited February, 2021\} Available from: http://www.iamj.in/posts/images/upload/466 472.pdf 